\title{
Associations between health and different types of environmental incivility: A Scotland-wide study
}

\author{
A. Ellaway ${ }^{\mathrm{a}, *}$, G. Morris $^{\mathrm{b}}$, J. Curtice ${ }^{\mathrm{c}}$, C. Robertson $^{\mathrm{d}}$, G. Allardice ${ }^{\mathrm{d}}$, R. Robertson ${ }^{\mathrm{e}}$ \\ ${ }^{a}$ MRC, Social and Public Health Sciences Unit, 4 Lilybank Gardens, Glasgow G12 8RZ, UK \\ ${ }^{\mathrm{b}}$ Department of Civil Engineering, University of Strathclyde, Glasgow, UK \\ ${ }^{\mathrm{c}}$ Department of Politics, University of Strathclyde, Glasgow, UK \\ ${ }^{\mathrm{d}}$ Department of Statistics and Modelling Science, University of Strathclyde, Glasgow, UK \\ ${ }^{\mathrm{e}}$ Health Protection Scotland, Glasgow, UK
}

Keywords:

Environmental justice

Health

Incivilities

Scotland

Neighbourhoods

\section{S U M M A R Y}

Objectives: Concern about the impact of the environment on health and well being has tended to focus on the physical effects of exposure to toxic and infectious substances, and on the impact of large scale infrastructures. Less attention has been paid to the possible psychosocial consequences of people's subjective perceptions of their everyday, street level environment, such as the incidence of litter and graffiti. As little is known about the potential relative importance for health of perceptions of different types of environmental incivility, a module was developed for inclusion in the 2004 Scottish Social Attitudes survey in order to investigate this relationship.

Study design: A random sample of 1637 adults living across a range of neighbourhoods throughout Scotland was interviewed.

Methods: Respondents were asked to rate their local area on a range of possible environmental incivil ities. These incivilities were subsequently grouped into three domains: (i) street level incivilities (e.g. litter, graffiti); (ii) large scale infrastructural incivilities (e.g. telephone masts); and (iii) the absence of environmental goods (e.g. safe play areas for children). For each of the three domains, the authors examined the degree to which they were thought to pose a problem locally, and how far these perceptions varied between those living in deprived areas and those living in less deprived areas. Subsequently, the relationships between these perceptions and self assessed health and health behav iours were explored, after controlling for gender, age and social class.

Results: Respondents with the highest levels of perceived street level incivilities were almost twice as likely as those who perceived the lowest levels of street level incivilities to report frequent feelings of anxiety and depression. Perceived absence of environmental goods was associated with increased anxiety ( 2.5 times more likely) and depression (90\% more likely), and a 50\% increased likelihood of being a smoker. Few associations with health were observed for perceptions of large scale infrastructural incivilities.

Conclusions: Environmental policy needs to give more priority to reducing the incidence of street level incivilities and the absence of environmental goods, both of which appear to be more important for health than perceptions of large scale infrastructural incivilities.

\section{Introduction}

There is increasing evidence that area of residence is associated with health, independently of individual characteristics such as age, gender or socio economic status. ${ }^{1,2}$ Potential explanations include

\footnotetext{
* Corresponding author. Tel.: +44 141357 3949; fax: +44 1413372389

E-mail address: anne@sphsu.mrc.ac.uk (A. Ellaway).
}

the distribution of amenities and facilities in an area, as well as how people perceive and interpret the place in which they live. ${ }^{3,4}$

Parallel to the growing public health literature on the impor tance of place in determining health, there is extensive literature on environmental justice. The term 'environmental justice' was first used in the USA in the late 1970s in response to the dispropor tionate burden placed on poor Black communities by the location of noxious facilities in their neighbourhoods. . $^{5}$

In Scotland, the initial public reference to environmental justice was in a speech given in February 2002 by the then First Minister: 
Too often the environment is dismissed as the concern of those who are not confronted with bread and butter issues. But the reality is that the people who have the most urgent environmental concerns in Scotland are those who daily cope with the consequences of a poor quality of life, and live in a rotten environment close to industrial pollution, plagued by vehicle emissions, streets filled with litter and walls covered in graffiti. This is true for Scotland and also true for elsewhere in the world. These are circumstances which would not be acceptable to better off communities in our society, and those who have to endure such environments in which to bring up a family, or grow old themselves are being denied environ mental justice (Jack McConnell, 2002).

This approach to environmental justice encompasses more than proximity to large scale toxic or infectious environmental health risks, which has been the preoccupation of much previous work on the relationship between environment and health. It draws atten tion to the potential psychosocial effects of environmental 'inci vilities' on human health and well being. An 'environmental incivility' is any aspect of the environment that people are capable of discerning through hearing, sight, touch or smell, and about which they may be inclined to feel negatively. These perceptions are thought to matter because of their potentially adverse psychological impact on the individual. Hence, it is not solely the objective physical environment that matters, but also people's subjective impressions of and then reactions to that environment. Meanwhile, although it is well established that people living in poorer areas in Scotland are more likely to be exposed to envi ronmental health risks, ${ }^{7}$ such as industrial pollution, derelict land, poor river water quality and poor air quality, less is known about whether similar relationships are found when one considers people's perceptions of their local environment.

The degree to which people perceive their residential environ ment to be pleasant or otherwise has been shown to be associated with various health outcomes, including self rated health ${ }^{8-14}$ and health behaviours such as smoking. ${ }^{15-17}$ Perceptions of the neigh bourhood may also influence health behaviours, such as walking around the local neighbourhood, ${ }^{18,19}$ that, in turn, can have an effect on social relationships in the neighbourhood. ${ }^{20}$ Residents who perceive higher levels of incivilities are less attached to their neighbourhood, and this is associated with high population turn over, ${ }^{21}$ lowered social trust and, in turn, more negative perceptions of the local neighbourhood. In addition, a large body of research ${ }^{22-25}$ has found that those who perceive a higher incidence of incivilities also have a greater fear of crime. Fear of crime has been shown to be associated with health and health related behaviours. ${ }^{26-30}$

The impact of the availability of 'environmental goods', such as somewhere green and pleasant to walk or sit, or places that are safe and pleasant for children to play, has also received some attention. A number of studies have shown positive health benefits of green areas on human health. ${ }^{31-33}$ Access to safe play areas is important for a number of child health and development outcomes, including achieving sufficient physical activity, reducing accidents and interacting with others. ${ }^{34-36}$

Infrastructural conditions have, of course, also been implicated. There is continuing debate over the possible health risks associated with living near overhead power lines ${ }^{37}$ or telephone masts. ${ }^{38}$ Sewage smells may constitute a nuisance, ${ }^{39}$ and a key indicator of the quality of the local physical environment is the quantity of derelict land. ${ }^{40}$

To date, most studies of the link between the local environ ment and health have been restricted to a particular geographic area and/or a small set of perceived environmental conditions. This study aimed to explore the reported incidence, distribution and impact of subjective environmental incivilities across the whole of Scotland. To investigate these questions, a module was designed for insertion in the 2004 Scottish Social Attitudes (SSA) survey. This exercise had two key strengths. First, it collected data on perceptions of large environmental burdens, such as landfill sites, a wide range of everyday street level incivilities and perceptions of the absence of environmental goods (green spaces and safe play areas). Second, it had national coverage, encompassing different locales, urban rural differences, and a wide sociodemographic and socio economic range of respondents.

\section{Methods}

\section{Sample design}

The 2004 SSA survey was designed to yield a representative sample of adults aged 18 years or over living in Scotland. The sample frame was the postcode address file; a list of postal delivery points compiled by the Post Office. The sample design involved three stages. Firstly, 84 postcode sectors were selected from a list of all postal sectors in Scotland, with probability proportional to the number of addresses in each sector. Prior to selection, the sectors were stratified by region, population density and percentage of household heads recorded as employers/managers (taken from the 2001 Census). The list was also stratified using the Scottish Household Survey (SHS) six fold classification of urban and rural areas, ${ }^{41}$ and sectors within rural and remote categories were oversampled. In order to boost the number of respondents from remote and rural areas further, twice as many addresses ( $n$ 62) were selected from the sectors within the three most rural categories (remote small towns to remote rural areas) than were selected from each sector located within the first three SHS urban rural classifications (cities to accessible small towns). Interviewers called at each selected address and identified its eligibility for the survey. Where more than one household was present at an address, all households were listed systematically and one was selected at random using a computer generated random selection table. In all eligible households that contained more than one adult aged 18 years or over, interviewers also had to carry out a random selection of one adult to be interviewed using a similar procedure. In total, 2699 addresses proved to be suitable for inclusion in the survey, and within these, 1637 individuals (60.7\%) completed the inter view. Interviews were conducted using face to face computer assisted interviewing, supplemented by a self completion questionnaire that was answered by $92 \%$ (1514) of respondents to the main interview.

Data were weighted to take account of the fact that not all households or individuals had the same probability of selection for the survey. For example, adults living in large households had a lower selection probability than adults who live alone. Weighting was also used to correct the oversampling of rural addresses.

\section{Variables}

\section{Sociodemographic measures}

Respondents were aged 1897 years (mean 50.15, standard deviation 17.8); 950 were female and 687 were male. SSA respon dents were classified, using the National Statistics Socio Economic Classification, ${ }^{42}$ according to their own occupation, rather than that of the head of the household. Each respondent was asked about their current or last job, so that all respondents, with the exception of those who had never worked, were classified. 
Table 1

Proportion of respondents reporting incivilities as a 'really big problem' by area deprivation category.

\begin{tabular}{|c|c|c|c|c|c|c|c|c|}
\hline & 1 (Least deprived) \% & $2 \%$ & $3 \%$ & $4 \%$ & $5 \%$ & $6 \%$ & 7 (Most deprived) \% & $n$ \\
\hline \multicolumn{9}{|l|}{ Street-level incivilities } \\
\hline Litter and rubbish & 7 & 10 & 7 & 7 & 11 & 14 & 24 & 393 \\
\hline Vandalism/graffiti & 4 & 2 & 3 & 6 & 7 & 13 & 29 & 495 \\
\hline Cat and dog mess & 5 & 12 & 13 & 16 & 19 & 25 & 33 & 540 \\
\hline Discarded needles & 2 & 1 & 1 & 1 & 1 & 4 & 14 & 229 \\
\hline Amount of traffic & 4 & 7 & 10 & 12 & 20 & 14 & 14 & 229 \\
\hline Dumped cars/'fridges etc. & 2 & 2 & 2 & 3 & 8 & 10 & 13 & 213 \\
\hline Broken glass & 5 & 3 & 5 & 2 & 7 & 9 & 17 & 278 \\
\hline Spraying of crops & 1 & 1 & 2 & 2 & 1 & 2 & 5 & 82 \\
\hline Untidy gardens/waste land & 3 & 1 & 2 & 3 & 5 & 7 & 12 & 196 \\
\hline Uneven pavements & 5 & 8 & 9 & 9 & 16 & 12 & 19 & 311 \\
\hline \multicolumn{9}{|l|}{ Infrastructural incivilities } \\
\hline Sewage smell & 2 & 2 & 5 & 6 & 5 & 9 & 9 & 147 \\
\hline Factory noise and smells & 0 & 2 & 0 & 3 & 1 & 3 & 1 & 16 \\
\hline Vacant/derelict buildings & 2 & 1 & 2 & 1 & 7 & 7 & 20 & 327 \\
\hline Overhead power lines & 0 & 1 & 1 & 0 & 1 & 1 & 1 & 16 \\
\hline \multicolumn{9}{|l|}{ Absence of environmental goods } \\
\hline Availability of safe play spaces & 4 & 7 & 8 & 10 & 23 & 25 & 45 & 736 \\
\hline Availability of pleasant places to walk etc. & 0 & 3 & 2 & 5 & 16 & 17 & 37 & 606 \\
\hline No. of respondents 1637 & 75 & 272 & 341 & 452 & 169 & 235 & 93 & \\
\hline
\end{tabular}

\section{Perceived incivilities}

Four primary approaches were used to identify the incivilities that should be explored by the study. These were: a review of relevant academic and 'grey' literature; the experience of the research team gained in previous work on the links between inci vilities and community well being; the views of local authority environmental health officers elicited prior to establishing the Environmental Health Surveillance System for Scotland ${ }^{43}$; and the views of Scottish Executive officials concerned with policy devel opment on environmental justice. This generated a list of 24 items. ${ }^{44}$ Respondents' feelings about the extent of a problem posed by a particular incivility were ascertained by presenting them with a set of seven faces that ranged from a face that was discernibly smiling to a face that was evidently unhappy. ${ }^{45}$ The happiest face was described as indicating that something was 'no problem at all', while the unhappiest face was labelled a 'really big problem'. Respondents were invited to indicate the face that best described how much of a problem each incivility was in their area.

In this paper, of the original list of 24 items, perceptions of the 16 most commonly reported potential incivilities are reported. Using factor analysis, three domains of incivilities emerged from the 16 items: street level incivilities (comprising litter and rubbish, vandalism and graffiti, dog and cat mess, discarded needles, traffic, dumped cars/'fridges etc., broken glass, spraying of crops, untidy gardens/waste land, uneven pavements), infrastructural incivilities (sewage smells, factory noise and smells, vacant or derelict

Table 2

Distribution of health and well-being variables by area deprivation.

\begin{tabular}{|c|c|c|c|c|c|c|c|}
\hline & $\begin{array}{l}1 \text { (Most } \\
\text { affluent) }\end{array}$ & & & & & & $\begin{array}{l}7 \text { (Most } \\
\text { deprived) }\end{array}$ \\
\hline & $\%$ & $\%$ & $\%$ & $\%$ & $\%$ & $\%$ & $\%$ \\
\hline $\begin{array}{l}\text { Feels anxious: } \\
\text { very or fairly } \\
\text { often }\end{array}$ & 9 & 12 & 12 & 13 & 23 & 25 & 23 \\
\hline $\begin{array}{l}\text { Feels sad: very or } \\
\text { fairly often }\end{array}$ & 14 & 14 & 13 & 15 & 20 & 28 & 26 \\
\hline $\begin{array}{l}\text { Health: very } \\
\text { bad or bad }\end{array}$ & 1 & 5 & 5 & 7 & 7 & 18 & 18 \\
\hline Current smoker & 27 & 21 & 25 & 30 & 42 & 45 & 44 \\
\hline $\begin{array}{l}\text { Has not walked } \\
1 \text { mile in past } \\
\text { year }\end{array}$ & 9 & 12 & 13 & 18 & 12 & 21 & 26 \\
\hline
\end{tabular}

buildings, overhead power lines) and absence of environmental goods (safe play spaces and pleasant places to walk or sit). For each of these three domains, a score was constructed by summing responses to each item comprising the domain. These scores were subsequently divided into quartiles, with those in the lowest quartile being the most positive, and those in the highest quartile being the most negative, about their local neighbourhood.

\section{Health and well being}

This study aimed to capture feelings of anxiety, depression and self rated general health by using questions that have been asked in previous surveys. First, respondents were asked, 'During the past 12 months, how often if at all have you been bothered by feelings of anxiety?' and, 'During the past 12 months, how often if at all have you been bothered by feeling sad or depressed?'. In both cases,

Table 3

Differences in health by street-level incivilities score after controlling for gender, age and social class.

\begin{tabular}{|c|c|c|c|}
\hline Health measure & $\begin{array}{l}\text { Street-level } \\
\text { incivilities score }{ }^{a}\end{array}$ & $\begin{array}{l}\text { Odds } \\
\text { ratio }\end{array}$ & $P<$ \\
\hline $\begin{array}{l}\text { More frequent feelings of } \\
\text { anxiety }\end{array}$ & $\begin{array}{l}1 \text { (Low) } \\
2 \\
3 \\
4 \text { (High) }\end{array}$ & $\begin{array}{l}1.00 \\
1.70 \\
1.38 \\
2.04\end{array}$ & $\begin{array}{l}1.01-2.650 .01 \\
0.88-2.16 \\
1.32-3.060 .001\end{array}$ \\
\hline $\begin{array}{l}\text { More frequent feelings of } \\
\text { sadness/depression }\end{array}$ & $\begin{array}{l}1 \text { (Low) } \\
2 \\
3 \\
4 \text { (High) }\end{array}$ & $\begin{array}{l}1.00 \\
1.56 \\
1.04 \\
1.82\end{array}$ & $\begin{array}{l}1.04-2.350 .03 \\
0.68-1.60 \\
1.23-2.700 .003\end{array}$ \\
\hline Poorer general health & $\begin{array}{l}1 \text { (Low) } \\
2 \\
3 \\
4 \text { (High) }\end{array}$ & $\begin{array}{l}1.00 \\
1.12 \\
0.98 \\
1.68\end{array}$ & $\begin{array}{l}0.79-1.60 \\
0.69-1.40 \\
1.20-2.340 .002\end{array}$ \\
\hline Smoker & $\begin{array}{l}1 \text { (Low) } \\
2 \\
3 \\
4 \text { (High) }\end{array}$ & $\begin{array}{l}1.00 \\
1.08 \\
1.11 \\
1.34\end{array}$ & $\begin{array}{l}0.78-1.48 \\
0.81-1.52 \\
0.98-1.82\end{array}$ \\
\hline $\begin{array}{l}\text { Has not walked } 1 \text { mile in past } \\
\text { year }\end{array}$ & $\begin{array}{l}1 \text { (Low) } \\
2 \\
3 \\
4 \text { (High) }\end{array}$ & $\begin{array}{l}1.00 \\
0.91 \\
0.70 \\
0.73\end{array}$ & $\begin{array}{l}0.60-1.38 \\
0.46-1.07 \\
0.48-1.13\end{array}$ \\
\hline
\end{tabular}

CI, confidence interval.

a 1 base category. 
Table 4

Differences in health by infrastructural incivilities score after controlling for gender, age and social class.

\begin{tabular}{llll}
\hline Health measure & $\begin{array}{l}\text { Infrastructural } \\
\text { incivilities score }^{\mathrm{a}}\end{array}$ & $\begin{array}{l}\text { Odds } \\
\text { ratio }\end{array}$ & $\mathrm{CI}$ \\
\hline More frequent feelings of & 1 (Low) & 1.00 & \\
anxiety & 2 & 0.98 & $0.64-1.48$ \\
& 3 & 0.83 & $0.55-1.24$ \\
& 4 (High) & 1.24 & $0.83-1.85$ \\
More frequent feelings of & 1 (Low) & 1.0 & \\
sadness/depression & 2 & 1.30 & $0.86-1.94$ \\
& 3 & 0.85 & $0.57-1.27$ \\
Poorer general health & 4 (High) & 1.53 & $1.04-2.270 .03$ \\
& 1 (Low) & 1.00 & \\
& 2 & 1.08 & $0.75-1.54$ \\
Smoker & 3 & 1.25 & $0.90-1.74$ \\
& 4 (High) & 1.36 & $0.97-1.93$ \\
& 1 (Low) & 1.00 & \\
& 2 & 0.87 & $0.63-1.20$ \\
Has not walked 1 mile in past & 1 (Low) & 0.87 & $0.65-1.17$ \\
year & 2 & 0.97 & $0.71-1.33$ \\
& 3 & 1.00 & \\
\hline
\end{tabular}

$\mathrm{CI}$, confidence interval.

a 1 base category.

respondents were asked to choose one of five possible options: 'very often', 'fairly often', 'sometimes', almost never' or 'never', with an additional option of 'can't choose'. In addition, respondents were asked to rate their own health compared with someone of their age by choosing one of the following options: 'very good', 'good', 'fair', 'bad' or 'very bad'.

\section{Health behaviour}

Respondents were asked whether or not they currently smoked. They were also asked whether they had taken a walk of around 1

Table 5

Differences in health by absence of environmental goods score after controlling for gender, age and social class.

\begin{tabular}{|c|c|c|c|}
\hline Health measure & $\begin{array}{l}\text { Absence of } \\
\text { environmental goods } \\
\text { score }^{a}\end{array}$ & $\begin{array}{l}\text { Odds } \\
\text { ratio }\end{array}$ & $P<$ \\
\hline $\begin{array}{l}\text { More frequent feelings of } \\
\text { anxiety }\end{array}$ & $\begin{array}{l}1 \text { (Low) } \\
2 \\
3 \\
4 \text { (High) }\end{array}$ & $\begin{array}{l}1.00 \\
1.08 \\
1.59 \\
2.44\end{array}$ & $\begin{array}{ll}0.70-1.68 & \\
1.03-2.46 & 0.035 \\
1.60-3.70 & 0.001\end{array}$ \\
\hline $\begin{array}{l}\text { More frequent feelings of } \\
\text { sadness/depression }\end{array}$ & $\begin{array}{l}1 \text { (Low) } \\
2 \\
3 \\
4 \text { (High) }\end{array}$ & $\begin{array}{l}1.00 \\
0.77 \\
1.26 \\
1.94\end{array}$ & $\begin{array}{l}0.51-1.17 \\
0.84-1.88 \\
1.31-2.860 .001\end{array}$ \\
\hline Poorer general health & $\begin{array}{l}1 \text { (Low) } \\
2 \\
3 \\
4 \text { (High) }\end{array}$ & $\begin{array}{l}1.0 \\
1.10 \\
1.44 \\
1.94\end{array}$ & $\begin{array}{ll}0.78-1.55 & \\
1.01-2.04 & 0.043 \\
1.37-2.76 & 0.001\end{array}$ \\
\hline Smoker & $\begin{array}{l}1 \text { (Low) } \\
2 \\
3 \\
4 \text { (High) }\end{array}$ & $\begin{array}{l}1.00 \\
0.90 \\
1.31 \\
1.48\end{array}$ & $\begin{array}{l}0.66-1.23 \\
0.96-1.80 \\
1.08-2.040 .01\end{array}$ \\
\hline $\begin{array}{l}\text { Has not walked } 1 \text { mile in } \\
\text { past year }\end{array}$ & $\begin{array}{l}1 \text { (Low) } \\
2 \\
3 \\
4 \text { (High) }\end{array}$ & $\begin{array}{l}1.0 \\
1.25 \\
1.73 \\
2.25\end{array}$ & $\begin{array}{ll}0.81-1.94 & \\
1.10-2.72 & 0.017 \\
1.44-3.51 & 0.001\end{array}$ \\
\hline
\end{tabular}

$\mathrm{CI}$, confidence interval.

a 1 base category. mile or more during the last year, including walking for pleasure as well as to and from work or the shops.

\section{Multivariate analysis}

In addition to ascertaining bivariate relationships, a series of logistic regression models were run in which gender, age and socio economic status were included, as well as each of the three inci vilities scales, divided into quartiles. The three five point measures (anxiety, depression and general health) were recoded into binary variables. The models thus estimate the odds of feeling anxious or depressed at least sometimes rather than never or almost never, while in the case of general health, they show the odds of someone saying that their health is poor or fair versus good or very good. All of the models have the lowest quartile (i.e. those reporting fewer problems) as the base category with which the other quartiles are compared.

\section{Results}

Table 1 reports the degree to which each of the 16 more commonplace incivilities (grouped under the three domains of street level incivilities, infrastructural incivilities and absence of environmental goods) were regarded as a 'really big problem' in their area by respondents in each of seven area deprivation cate gories. ${ }^{46}$ For all of the incivilities (with the exception of the amount of traffic item), respondents in the most deprived areas were the most negative about their local environment. This was particularly marked for the absence of environmental goods domain; indeed, almost half of the respondents in the most deprived area reported a 'really big problem' with a lack of safe play areas for children. Those living in the most deprived areas (20\%) were also 10 times more likely than those living in the least deprived areas (2\%) to say that vacant and derelict buildings were a big problem where they lived.

As Table 2 shows, a higher proportion of respondents living in more deprived areas reported poor health and health behaviours compared with those living in more affluent areas. Moreover, even after taking age, gender and social class into account, those who reported the highest incidence of street level incivilities were more likely to report poor health than those with more positive views on this aspect of the local environment. As Table 3 shows, according to the logistic regression, those with the highest incidence of street level incivilities were twice as likely as those with the lowest incidence of street level incivilities to report anxiety, 1.8 times more likely to report that they get depressed and 1.7 times more likely to report that they are not in good health. All of these differences were statistically significant. Those with the highest level of street level incivilities were also one third more likely to report that they smoke, although this difference was not quite statistically significant at the $5 \%$ level.

In contrast, the multivariate analysis suggests that there is little relationship between infrastructural incivilities and health (see Table 4). Only depression was reported significantly more often by those with a high score on this scale as opposed to those with a low score, although those with a high score were also less likely to report that they had not taken a walk of 1 mile or more in the last year.

Finally, the multivariate analysis confirmed the expectation of a strong relationship between reported health and the absence of environmental goods (see Table 5). Subjects who reported the highest absence of environmental goods also reported significantly higher levels of anxiety, depression and poor general health, and were significantly more likely to smoke and not to have taken a walk of 1 mile or more in the last year. 


\section{Discussion}

This study found that street level incivilities and perceived absence of environmental goods are related to health, with those who experience such incivilities being more likely to report feelings of depression, anxiety and poor health. In addition, the perceived absence of environmental goods was linked with poor health behaviours, such as smoking and lack of exercise. However, these patterns were largely absent for infrastructural incivilities. These results underline the relative importance of street level incivilities and environmental goods to people's well being. These are, of course, incivilities to which some sections of the population are far more likely to be exposed than others.

However, there is a need for some caution in interpreting these results. This study has shown the existence of cross sectional associations between health and perceptions of the local environ ment. This does not necessarily prove that the latter causes the former. In particular, it is possible that those with low self reported health and who feel that their environment is poor may simply be reflecting a general underlying pessimism, i.e. they feel negative about all aspects of their lives. ${ }^{47}$ However, this potential bias is less likely to account for the relationship that was found between experience of incivilities and smoking behaviour, as smoking behaviour is a reported action rather than a subjective assessment of well being.

Although health is improving overall in Scotland, there are still large differences by area deprivation ${ }^{48}$ and some of this can be explained by indicators of environmental incivilities. Improve ments to local areas may be a strategy to increase environmental justice and reduce sociogeographic variations in health.

The results of this study suggest the need to cast the net more widely in public health, ${ }^{49}$ and to recognize that traditional envi ronmental and public health practice is too narrow in focus, compartmentalized and hazard based. A 21st Century environ mental health agenda should not only seek to ensure that the environment is free from physical, toxic, infectious and allergic hazards, but also that the environment nurtures positive health and well being, and fosters resilience. Such a commitment would also make an important contribution to ensuring greater equity in health.

\section{Ethical approval}

The Scottish Social Attitudes survey was undertaken in full compliance with NatCen's ethical code of conduct.

\section{Funding}

The Environmental Justice module for inclusion in the SSA survey was funded by the Scottish Executive.

\section{Competing interests}

None declared.

\section{References}

1. Pickett K, Pearl M. Multilevel analyses of neighbourhood socioeconomic context and health outcomes: a critical review.J Epidemiol Community Health 2001;55:111-22.

2. Riva M, Gauvin L, Barnett T. Toward the next generation of research into smal area effects on health: a synthesis of multilevel investigations published since July 1998. J Epidemiol Community Health 2007;61:853-61.

3. Macintyre S, Ellaway A. Ecological approaches: rediscovering the role of the physical and social environment. In: Berkman L, Kawachi, editors. Social epidemiology. Oxford: Oxford University Press; 2000.

4. Macintyre S, Ellaway A, Cummins S. Place effects on health: how can we conceptualise, operationalise and measure them? Soc Sci Med 2002;55:125-39.
5. Brown P. Race, class and environmental health: a review and systematization of the literature. Environ Res 1995;69:15-30.

6. Northridge ME, Stover GN, Rosenthal JE, Sherard D. Environmental equity and health: understanding complexity and moving forward. Am J Public Health 2003;93:209-14.

7. Fairburn J, Walker G, Smith G, Mitchell G. Investigating environmental justice in Scotland: links between measures of environmental quality and social deprivation. Edinburgh: SNIFFER; 2005.

8. Bowling A, Barber J, Morris R, Ebrahim S. Do perceptions of neighbourhood environment influence health? Baseline findings from a British survey of aging. J Epidemiol Community Health 2006;60:476-83.

9. Ellaway A, Macintyre S. Women in their place: gender and perceptions of neighbourhoods in the West of Scotland. In: Dyck I, Davis Lewis N, McLafferty S, editors. Geographies of women's health. New York: Routledge; 2001.

10. Ellaway A, Macintyre S, Kearns A. Perceptions of place and health in socially contrasting neighbourhoods. Urban Stud 2001;38:2299-316.

11. Pampalon R, Hamel D, De Koninck M, Disant MJ. Perception of place and health: differences between neighbourhoods in the Quebec City region. Soc Sci Med 2007;65:95-111.

12. Poortinga W, Dunstan FD, Fone DL. Perceptions of the neighbourhood environment and self rated health: a multilevel analysis of the Caerphilly Health and Social Needs Study. BMC Public Health 2007;7:285-95.

13. Steptoe A, Feldman PJ. Neighborhood problems as sources of chronic stress: development of a measure of neighborhood problems, and associations with socioeconomic status and health. Ann Behav Med 2001;23:177-85.

14. Yen I, Yelin E, Katz P, Eisner M, Blanc P. Perceived neighborhood problems and quality of life, physical functioning and depressive symptoms among adults with asthma. Public Health 2006;96:873-9.

15. Ellaway A, Macintyre S. Are perceived neighbourhood problems associated with the likelihood of smoking? J Epidemiol Community Health 2009;63:78-80.

16. Miles R. Neighborhood disorder and smoking: findings of a European urban survey. Soc Sci Med 2006;63:2464-75.

17. van Lenthe FJ, Mackenbach JP. Neighbourhood and individual socioeconomic inequalities in smoking: the role of physical neighbourhood stressors. J Epidemiol Community Health 2006;60:699-705.

18. Ross CE, Mirowsky J. Neighborhood disadvantage, disorder, and health. J Health Soc Behav 2001;42:258-76.

19. Ross CE. Walking, exercising, and smoking: does neighborhood matter? Soc Sci Med 2000;51:265-74.

20. Skjaeveland O, Garling T. Effects of interactional space on neighbouring. $J$ Environ Psychol 1997;17:181-98.

21. Brown B, Perkins DD, Brown G. Place attachment in a revitalizing neighborhood: individual and block levels of analysis. J Environ Psychol 2003;23:259-71.

22. Herbert D. Neighborhood incivilities and the study of crime in place. Area 1993;25:45-54.

23. Lagrange RL, Ferraro KF, Supancic M. Perceived risk and fear of crime - role of social and physical incivilities. J Res Crime Delinq 1992;29:311-34.

24. Austin DM, Furr LA, Spine M. The effects of neighborhood conditions on perceptions of safety. J Crim Justice 2002;30:417-27.

25. Robinson JB, Lawton BA, Taylor RB, Perkins DD. Multilevel longitudinal impacts of incivilities: fear of crime, expected safety, and block satisfaction. J Quant Criminol 2003;19:237-74.

26. Chandola T. The fear of crime and area differences in health. Health Place 2001;7:105-16.

27. Green G, Gilbertson J, Grimsley M. Fear of crime and health in residential tower blocks - a case study in Liverpool, UK. Eur J Public Health 2002;12:10-5.

28. Harrison R, Gemmell I, Heller R. The population effect of crime and neighbourhood on physical activity: an analysis of 15,461 adults. J Epidemiol Community Health 2007;61:34-9.

29. Lindstrom M, Merlo J, Ostergren P. Social capital and sense of security in the neighbourhood: a population based multilevel analysis in Malmo, Sweden. Soc Sci Med 2003;5:1111-20.

30. Stafford M, Chandola T, Marmot M. Association between fear of crime and mental health and physical functioning. Am J Public Health 2007:97:2076-81.

31. de Vries S, Verheij R, Groenewegen P, Spreeuwenberg P. Natural environments - healthy environments? An exploratory analysis of the relationship between greenspace and health. Environ Plan A 2003;35:1717-31.

32. Maas J, Verheij RA, Groenewegen PP, de Vries S, Spreeuwenberg P. Green space, urbanity, and health: how strong is the relation? J Epidemiol Community Health 2006;60:587-92.

33. Mitchell R, Popham F. Greenspace, urbanity and health: relationships in England. J Epidemiol Community Health 2007;61:681-3.

34. Cole-Hamilton I, Harrop A, Street C. Making the case for play: gathering the evidence. London: National Childrens Bureau; 2002.

35. McNeish D, Roberts H. Playing it safe: today's children at play. Ilford: Barnardo's; 1995.

36. von Kries R, Kohne C, Bohm O, von Voss H. Road injuries in school age children: relation to environmental factors amenable to interventions. Inj Prev 1998;4: 103-5.

37. Watts G. Power to confuse. BMJ 2005;330:1293.

38. Burgess A. Comparing national responses to perceived health risks from mobile phone masts. Health Risk Soc 2002;4:175-88.

39. DEFRA. Code of practice on odour nuisance from sewage treatment works. DEFRA; 2006

40. Scottish Government. Social focus on deprived areas. Edinburgh: Scottish Government; 2005. 
41. Hope S, Braunholtz S, Playfair A, Dudleston A, Ingram D, Martin C, et al. Scotland's people: results from the 1999 Scottish Household Survey, vol. 1. Edinburgh: Scottish Executive; 2000.

42. Rose D, Pevalin D. The national statistics socio-economic classification: unifying official and sociological approaches to the conceptualisation and measurement of social class. Colchester: University of Essex; 2001.

43. Henton I. Available from: http://www.documents.hps.scot.nhs.uk/ewr/pdf2007/ 0734.pdf last accessed 19 October 2009.

44. Curtice J, Ellaway A, Robertson C, Morris G, Allardice G, Robertson R. Public attitudes and environmental justice in Scotland: a report for the Scottish Executive on research to inform the development and evaluation of environmental justice policy. Edinburgh: Scottish Executive; 2005.
45. Andrews FM, Withey SB. Social indicators of well being: perceptions of life quality. New York: Plenum Press; 1976.

46. McLoone P. Carstairs Scores for Scottish Postcode Sectors from the 2001 Census Glasgow: MRC Social \& Public Health Sciences Unit; 2004.

47. Stansfeld S, Davey Smith G, Marmot M. Association between physical and psychological morbidity in the Whitehall II Study. J Psychosom Res 1993;37:227-38

48. Leyland AH. Socioeconomic gradients in the prevalence of cardiovascular disease in Scotland: the roles of composition and context. J Epidemiol Community Health 2005;59:799-803.

49. Morris G, Beck S, Hanlon P, Robertson R. Getting strategic about environment and health. Public Health 2006;120:889-907. 